\title{
The Interaction Design Strategy of Foreign Exchange Students on Network Field
}

\author{
Shang Dan ${ }^{1}$, Xiang Yuanwei ${ }^{2} \&$ Guan Yongxin ${ }^{2}$ \\ ${ }^{1}$ School of English for International Business, Guangdong University of Foreign Studies \\ ${ }^{2}$ School of Business, Guangdong University of Foreign Studies \\ Correspondence: Shang Dan, School of English for International Business, Guangdong University of Foreign \\ Studies, China.
}

Received: October 7, 2020

doi:10.5539/mas.v14n12p34

\author{
Accepted: November 16, 2020 \\ Online Published: November 18, 2020 \\ URL: https://doi.org/10.5539/mas.v14n12p34
}

\begin{abstract}
In the background of the Belt and Road initiative, international exchanges and cooperation are increasingly frequent and the number of students studying abroad is on the rise. Foreign exchange students living abroad are easily influenced by the environment, field culture, discourse subject etc, so that it's common for their ideas to be impacted. Cultural adaptation and avoiding western cultural osmosis are extraordinarily important in the management of foreign exchange students. Field theory provides a new means to resolve this problem. By using questionnaire to collect data and through behavior event interview, understand the behavior of foreign exchange students in the use of new media. And then, design user portrait according to the data results and interview content and construct the field environment elements of online education.
\end{abstract}

Keywords: network field, foreign exchange students, new media

In recent years, foreign exchange is a common learning method for international communication in the College and universities. Due to the advantages of saving time, low cost and simple procedures, this learning method is becoming a new form of international communication in College and universities. At the same time, because the time of foreign exchange is during period of students' college years, the schools which dispatch students have major responsibility for the management and education of these exchange students. Confronting cultural conflicts and contradictions caused by customs and habits, exchange students' ideas are vulnerable to impact. It is necessary to discuss the education and management of foreign exchange students.

\section{Introduction}

Pierre Bourdieu, a famous French sociologist, introduced the concept of field. He believed that the social network is the basic component of the field. The social world is composed of a large number of relatively autonomous small worlds which have their own logic and the space of objective relation of inevitability. These spaces constitute different fields of society, and each field has its own unique value and regulation principle, which defines the space of a society. Different fields are independent of each other and follow their own unique operation logic so that mutual expansion and change will lead to multi-dimensional changes. The education and management of foreign exchange students will be more efficient and realistic with the help of network media in the process of education and management of foreign exchange students. In the field that is opened up for online education, subjects and objects all follow the rules of this field, based on which make the policy to manage and educate exchange students. Cyberspace is a virtual projection of social space, which not only follows the rules of social space, but also avoids the limitations of real social space distance. Under the condition of space distance, the concept of field and its theory, on the one hand explain the change of students' life field which not only refers to the domestic and foreign regions, but also refers to the online and offline space, leading the change of personal behaviors and value choices, on the other hand, provides new ideas for how to deal with this change.

Recently researches on network ideological and political education in Colleges and Universities mainly focus on the following aspects. First, focus on how to occupy the network position. Second, focus on establishing and perfecting the network laws and regulations and strengthening the supervision. Third, focus on establishment and maintenance of ideological and political work team on Internet. Forth, focus on educational management of new media. Some of researches start with the problems in the new media era. (Zhao Yanwu, Li Xin, Zhang Wei, 
Ramir S. Austria, 2019), (Lu Jinxin, 2019) Some of researches propose that implement policies for different groups and audiences (Pang Juan, 2019) (Cai Chunhua, 2019) (Ding Yuan, 2019) Some propose that combinate network field and ideological and political education, such as cultural field construction of ideological and political education for College Students. (Ao Yongchun, Zhang Zhenqing, 2020) Some analysis the discourse power of Ideological and political education in Colleges and Universities under the network discourse field. (Deng Peng, Chen Shuwen, 2019) The above research has a shortcoming that is mainly focusing on the environment of Internet, without thinking about characteristics of campus network. Every university has its own campus network system, especially in the respects of various information resources and public opinion. What's more, its network technology and management methods are different from the general Internet environment. Therefore, it is necessary to locate the environment of network ideological and political education in the field of campus network so as to strengthen the pertinence and effectiveness of network ideological and political education.

Based on the analysis of the elements of online education field maintenance, this paper puts forward the interactive design strategy. "Network education field simulates learning community, which needs following elements, network education environment, activity subject, community consciousness and so on. The network education environment includes network hardware facilities, online learning platform, teaching resources and other supporting environment for carrying out teaching activities." Different from the App design for commercial purposes, the field of online education for foreign exchange students is hoped to be constructed in the campus network community environment, with emphasis on the implantation of educational ideas and cultural symbols. There are two kinds of main participants in the field of online education for foreign exchange students. Undoubtedly, one is the exchange students, and the other is the stuff appointed by the college. Although the staffs are more in the role of the operator, we need to consider their usage and the guiding role they play in the process of user research, because they also have using experience and needs in this process. The portrait of the main participants of the activity needs to be integrated with the social environment, psychological needs and other situations. While the social environment includes the family background, life scenes and living state of the participants, etc, psychological needs include belief, values and emotional states, etc. The social individual is the synthesis of the individual's internal and external social which is the key part of interaction design in network education field and the important factor for smooth operation and avoiding not accepted by others.

The value of interaction design is that the emotion, value, preference and other needs of the participants will be fully considered, making full use of a variety of ways to establish various communication channels among all participants including exchange students and managers of the network education field, eliminating the loneliness of exchange students, establishing a network education field for exchange students and making them have a sense of belonging.

\section{Data Sources, Sample Selection and Statistical Analysis}

In order to investigate foreign exchange, questionnaires were distributed online in colleges and universities in Guangdong Province through convenient sampling and 285 questionnaires were collected. And then use Excel 2010 software to input data and SPSS 22 software for statistical analysis of data.

\subsection{Base Situation of the Respondents}

From Table 1, we can see the following situation. (1)The sex ratio of respondents is 1.4:8.6. (2) The number of freshmen, junior, senior exchange students is basically the same and the number of sophomore exchange students is relatively small. (3) While Communist Youth League members accounted for $42.1 \%$ of all respondents, which is the biggest proportion. Communist Party members accounting for $28.1 \%$ of all respondents, which is the second biggest proportion. The vast majority of exchange students are over 18 years old accounting for $94.7 \%$ of all respondents. Most are those who are major in literature (49.1\%) and management (29.8\%). Most of respondents are undergraduate students of key universities (61.4\%) and ordinary undergraduate $(24.6 \%)$ students. 
Table 1. Statistical tables of the respondents $(n=285)$

\begin{tabular}{llll}
\hline & & Quantity & Proportion \\
\hline \multirow{2}{*}{ Gender } & Male & 40 & $14.00 \%$ \\
& Female & 245 & $86.00 \%$ \\
\hline \multirow{3}{*}{ Grade } & Freshman & 85 & $29.80 \%$ \\
& Freshman & 45 & $15.80 \%$ \\
& Junior & 75 & $26.30 \%$ \\
Political status & Senior & 80 & $28.10 \%$ \\
\hline \multirow{2}{*}{ Age } & Communist Party member & 80 & $28.10 \%$ \\
& Communist Party activists & 40 & $14.00 \%$ \\
\hline & Communist youth league member & 120 & $42.10 \%$ \\
& General public & 45 & $15.80 \%$ \\
\hline Major & Under 18 & 15 & $5.30 \%$ \\
& 18 and over & 270 & $94.70 \%$ \\
\hline & Economics & 25 & $8.80 \%$ \\
& Pedagogics & 10 & $3.50 \%$ \\
& Literature & 140 & $49.10 \%$ \\
& Management & 85 & $29.80 \%$ \\
\hline & Key or 211 or both & 35 & $12.30 \%$ \\
& General undergraduate & 70 & $24.60 \%$ \\
& Higher Vocational Colleges & 5 & $1.80 \%$ \\
& Key undergraduate & 175 & $61.40 \%$ \\
\hline
\end{tabular}

\subsection{Overall Portrait of the Respondents}

From Table 2, among the respondents, most of them daily use network over 5 hours on average. Those who daily use network 5 to 6 hours accounts for $29.8 \%$ of all respondents. Those who daily use network over 6 hours accounts $52.6 \%$ of all respondents and those who weekly use network over 6 days accounts for $94.7 \%$ of all respondents. Besides, those who like simple interface accounts for $94.7 \%$ of all respondents when using new media.

Table 2. Basic Portraits of foreign Exchange Student as Network Users $(n=285)$

\begin{tabular}{llll}
\hline & & Quantity & Proportion \\
\hline & Less than 2 hours & 15 & 5.30 \\
Average time per day using the network & $2-4$ hours & 35 & 12.30 \\
& $5-6$ hours & 85 & 29.80 \\
& Over 6 hours & 150 & 52.60 \\
\hline \multirow{2}{*}{ Average number of days per week using the network } & Less than 2 days & 0 & 0 \\
& 2-4 days & 5 & 1.80 \\
& 5-6 days & 10 & 3.50 \\
\hline \multirow{2}{*}{ Preferences of Interface on new media } & More than 6 days & 270 & 94.70 \\
& concise & 270 & 94.70 \\
\hline
\end{tabular}

From Table 3, portraits of foreign exchange students as a network user are ranked according to the score from high to low.

Attention to current political issues $>$ Attention to New Media for State Government $>$ Attention to School Official New Media $>$ Attention to ethic issues $>$ Attention to religious issues $>$ Express own views and 
comments on current events through WeChat, QQ or Weibo > Forward or comment on ethnic information through WeChat, QQ or Weibo > Forward or comment on religious information through WeChat, QQ or Weibo > Meet the negative comments on questioning ethnic or religious issues on WeChat, QQ or Weibo.

Table 3. Score of Portraits of Network Users of Foreign Exchange Students $(n=285)$

\begin{tabular}{ll}
\hline Project & $x_{ \pm \mathrm{r}}$ \\
\hline Attention to School Official New Media & $3.42 \mathrm{ntion}$ \\
Attention to New Media for State Governme & 3.61 rnmen \\
Attention to current political issues & $3.75 \mathrm{ntion}$ \\
Attention to religious issues & $3.14 \mathrm{ntion}$ \\
Attention to ethic issues & $3.39 \mathrm{ntion}$ \\
Express own views and comments on current events through WeChat, QQ or Weibo & 2.21 oor W \\
Forward or comment on ethnic information through WeChat, QQ or Weibo & 2.1600 W \\
Forward or comment on religious information through WeChat, QQ or Weibo & 1.91 loor W \\
Forward or comment on religious information through WeChat, QQ or Weibo & 1.5600 W \\
\hline
\end{tabular}

\subsection{Comparison of Portraits of Different Groups of Internet Users}

From table 4, it is of statistical significance to compare the differences of the Internet time yesterday between different genders of respondents, which shows students of different genders used the Internet for different hours yesterday. By the way, it is not of statistical significance of differences of the days of using the Internet last week and preferred interface for respondents of different genders using new media.

Table 4. Comparison of basic portraits of Internet users of different genders

\begin{tabular}{|c|c|c|c|c|c|}
\hline & & Male & Female & Chi-square value & $\mathrm{P}$ \\
\hline \multirow{4}{*}{$\begin{array}{l}\text { The time of Students of different genders } \\
\text { used the Internet yesterday }\end{array}$} & Less than 2 hours & $0(0 \%)$ & $15(6.10 \%)$ & 21.68 & 0 \\
\hline & 2-4 hours & $10(25 \%)$ & $25(10.20 \%)$ & & \\
\hline & 5-6 hours & $20(50 \%)$ & $65(26.50 \%)$ & & \\
\hline & Over 6 hours & $10(25 \%)$ & $140(57.10 \%)$ & & \\
\hline \multirow{4}{*}{$\begin{array}{l}\text { The number of days of students of different } \\
\text { genders using Internet last week }\end{array}$} & less than 2 days & $0(0 \%)$ & $0(0 \%)$ & 2.59 & 0.28 \\
\hline & 2-4 days & $0(0 \%)$ & $5(2 \%)$ & & \\
\hline & 5-6 days & $0(0 \%)$ & $10(4.10 \%)$ & & \\
\hline & Over 6 days & $40(100 \%)$ & $230(93.90 \%)$ & & \\
\hline \multirow{2}{*}{$\begin{array}{l}\text { Preferred interface for students of different } \\
\text { genders when using new media }\end{array}$} & concise & $40(100 \%)$ & $230(93.90 \%)$ & 2.59 & 0.11 \\
\hline & exquisite & $0(0 \%)$ & $15(6.10 \%)$ & & \\
\hline
\end{tabular}

Table 5. Comparison of Basic Portraits of Internet Users of Different Grades

\begin{tabular}{|c|c|c|c|c|c|c|c|}
\hline & & Freshman & Sophomore & Junior & Senior & $\begin{array}{l}\text { Chi-square } \\
\text { value }\end{array}$ & $\mathrm{P}$ \\
\hline \multirow{4}{*}{$\begin{array}{l}\text { The time of network } \\
\text { usage of students of } \\
\text { different grades }\end{array}$} & Less than 2 hours & $0(0 \%)$ & $0(0 \%)$ & $0(0 \%)$ & $15(18.80 \%)$ & 66.74 & 0 \\
\hline & 2-4 hours & $10(11.80 \%)$ & $10(22.20 \%)$ & $0(0 \%)$ & $15(18.80 \%)$ & & \\
\hline & 5-6 hours & $35(41.20 \%)$ & $10(22.20 \%)$ & $25(33.30 \%)$ & $15(8.80 \%)$ & & \\
\hline & Over 6 hours & $40(47.10 \%)$ & $25(55.60 \%)$ & $50(66.70 \%)$ & $35(3.80 \%)$ & & \\
\hline \multirow{4}{*}{$\begin{array}{l}\text { The number of days of } \\
\text { network usage of } \\
\text { students of different } \\
\text { grades }\end{array}$} & Less than 2 days & $0(0 \%)$ & $0(0 \%)$ & $0(0 \%)$ & $0(0 \%)$ & 27.42 & 0 \\
\hline & 2-4 days & $0(0 \%)$ & $0(0 \%)$ & $0(0 \%)$ & $5(6.30 \%)$ & & \\
\hline & 5-6 days & $5(5.90 \%)$ & $5(11.10 \%)$ & $0(0 \%)$ & $0(0 \%)$ & & \\
\hline & Over 6 days & $80(94.10 \%)$ & $40(88.90 \%)$ & $75(100 \%)$ & $75(93.80 \%)$ & & \\
\hline \multirow{2}{*}{$\begin{array}{l}\text { The style of interface } \\
\text { preferred by students of } \\
\text { different grades }\end{array}$} & concise & $80(94.10 \%)$ & $45(100 \%)$ & $70(93.30 \%)$ & $75(93.80 \%)$ & 3.02 & 0.39 \\
\hline & exquisite & $5(5.90 \%)$ & $0(0 \%)$ & $5(6.70 \%)$ & $5(6.30 \%)$ & & \\
\hline
\end{tabular}


According to Table 6, among respondents, with different political identities there are significant differences in the using the network yesterday, the number of days using the network last week, and the preferred style of the interface when using new media $(\mathrm{P}<0.05)$.

Table 6. Comparison of the Portraits of Online Users of the students with Different Political Features

\begin{tabular}{|c|c|c|c|c|c|c|c|}
\hline & & $\begin{array}{l}\text { the Communist } \\
\text { Party members }\end{array}$ & $\begin{array}{l}\text { the Communist } \\
\text { Party activists }\end{array}$ & $\begin{array}{l}\text { communist youth } \\
\text { league member }\end{array}$ & general public & $\begin{array}{l}\text { Chi-square } \\
\text { value }\end{array}$ & $\mathrm{P}$ \\
\hline \multirow{4}{*}{$\begin{array}{l}\text { The Internet time } \\
\text { students with } \\
\text { different political } \\
\text { identities used } \\
\text { yesterday }\end{array}$} & Less than 2 hours & $0(0 \%)$ & $0(0 \%)$ & $5(4.20 \%)$ & $10(22.20 \%)$ & 52.93 & 0 \\
\hline & 2-4 hours & $10(12.50 \%)$ & $10(25 \%)$ & $10(8.30 \%)$ & $5(11.10 \%)$ & & \\
\hline & 5-6 hours & $25(31.30 \%)$ & $10(25 \%)$ & $30(25 \%)$ & $20(44.40 \%)$ & & \\
\hline & Over 6 hours & $45(56.30 \%)$ & $20(50 \%)$ & $75(62.50 \%)$ & $10(22.20 \%)$ & & \\
\hline \multirow{4}{*}{$\begin{array}{l}\text { The number of days } \\
\text { students with } \\
\text { different political } \\
\text { identities used the } \\
\text { network last week }\end{array}$} & Less than 2 days & $0(0 \%)$ & $0(0 \%)$ & $0(0 \%)$ & $0(0 \%)$ & 31.81 & 0 \\
\hline & 2-4 days & $0(0 \%)$ & $0(0 \%)$ & $0(0 \%)$ & $5(11.10 \%)$ & & \\
\hline & 5-6 days & $5(6.30 \%)$ & $0(0 \%)$ & $5(4.20 \%)$ & $0(0 \%)$ & & \\
\hline & Over 6 days & $75(93.80 \%)$ & $40(100 \%)$ & $115(95.80 \%)$ & $40(88.90 \%)$ & & \\
\hline $\begin{array}{l}\text { The preferred style } \\
\text { of interface of } \\
\text { students with } \\
\text { different political } \\
\text { identities using new } \\
\text { media }\end{array}$ & exquisite & $75(93.80 \%)$ & $35(87.50 \%)$ & $120(100 \%)$ & $40(88.90 \%)$ & 14.11 & 0.01 \\
\hline
\end{tabular}

Table 7 shows that the differences in the Internet time yesterday of respondents of different ages are statistically significant $(\mathrm{P}<0.05)$. But the differences in the number of days using Internet last week of respondents of different ages and the preferred style of the interface of different genders are not statistically significant $(\mathrm{P}>0.05)$.

Table 7. Comparison of Online User Portraits of Respondents of Different Age

\begin{tabular}{|c|c|c|c|c|c|}
\hline & & Under 18 & 18 and over & Chi-square value & $P$ \\
\hline \multirow{4}{*}{$\begin{array}{l}\text { the Internet time } \\
\text { yesterday of the students } \\
\text { of different ages }\end{array}$} & Less than 2 hours & $5(33.30 \%)$ & $10(3.70 \%)$ & 26.83 & 0 \\
\hline & 2-4 hours & $0(0 \%)$ & $35(13 \%)$ & & \\
\hline & 5-6 hours & $5(33.30 \%)$ & $80(29.60 \%)$ & & \\
\hline & Over 6 hours & $5(33.30 \%)$ & $145(53.70 \%)$ & & \\
\hline \multirow{4}{*}{$\begin{array}{l}\text { the number of days used } \\
\text { Internet by students of } \\
\text { different ages last week }\end{array}$} & Less than 2 days & $0(0 \%)$ & $0(0 \%)$ & 0.88 & 0.64 \\
\hline & 2-4 days & $0(0 \%)$ & $5(1.90 \%)$ & & \\
\hline & 5-6 days & $0(0 \%)$ & $10(3.70 \%)$ & & \\
\hline & More than 6 days & $15(100 \%)$ & $255(94.40 \%)$ & & \\
\hline \multirow{2}{*}{$\begin{array}{l}\text { the preferred style of the } \\
\text { interface of students of } \\
\text { different genders when } \\
\text { using new media }\end{array}$} & concise & $15(100 \%)$ & $255(94.40 \%)$ & 0.88 & 0.35 \\
\hline & exquisite & $0(0 \%)$ & $15(5.60 \%)$ & & \\
\hline
\end{tabular}

Table 8 shows that there are significant differences in the Internet time yesterday of the respondents of different ages $(\mathrm{P}<0.05)$, and there is no significant difference in last week the number of days of respondents using Internet of different ages and the preferred style of interface when using new media $(\mathrm{P}>0.05)$. 
Table 8. Comparison of Internet User Portraits for Students of Different Types of Schools

\begin{tabular}{|c|c|c|c|c|c|c|c|}
\hline & & $\begin{array}{l}985 \text { or } 211 \text { or } \\
\text { both }\end{array}$ & $\begin{array}{l}\text { Key } \\
\text { undergraduate }\end{array}$ & $\begin{array}{l}\text { General } \\
\text { undergraduate }\end{array}$ & $\begin{array}{l}\text { Higher } \\
\text { Vocational } \\
\text { Colleges }\end{array}$ & $\begin{array}{l}\text { Chi-square } \\
\text { value }\end{array}$ & $\mathrm{P}$ \\
\hline \multirow{4}{*}{$\begin{array}{l}\text { The Internet time } \\
\text { yesterday of Students } \\
\text { of different types of } \\
\text { school }\end{array}$} & $\begin{array}{l}\text { Less than } 2 \\
\text { hours }\end{array}$ & $5(14.30 \%)$ & $0(0 \%)$ & $0(0 \%)$ & $10(5.70 \%)$ & \multirow[t]{4}{*}{54.88} & \multirow[t]{4}{*}{0} \\
\hline & 2-4 hours & $5(14.30 \%)$ & $5(7.10 \%)$ & $0(0 \%)$ & $25(14.30 \%)$ & & \\
\hline & 5-6 hours & $5(14.30 \%)$ & $40(57.10 \%)$ & $5(100 \%)$ & $35(20 \%)$ & & \\
\hline & $\begin{array}{l}\text { More than } 6 \\
\text { hours }\end{array}$ & $20(57.10 \%)$ & $25(35.70 \%)$ & $0(0 \%)$ & $105(60 \%)$ & & \\
\hline \multirow{4}{*}{$\begin{array}{l}\text { The number of days } \\
\text { using Internet of } \\
\text { students of different } \\
\text { types of school }\end{array}$} & $\begin{array}{l}\text { Less than } 2 \\
\text { days }\end{array}$ & $0(0 \%)$ & $0(0 \%)$ & $0(0 \%)$ & $0(0 \%)$ & \multirow[t]{4}{*}{9.95} & \multirow[t]{4}{*}{0.13} \\
\hline & 2-4 days & $0(0 \%)$ & $0(0 \%)$ & $0(0 \%)$ & $5(2.90 \%)$ & & \\
\hline & 5-6 days & $0(0 \%)$ & $0(0 \%)$ & $0(0 \%)$ & $10(5.70 \%)$ & & \\
\hline & $\begin{array}{l}\text { More than } 6 \\
\text { days }\end{array}$ & $35(100 \%)$ & $70(100 \%)$ & $5(100 \%)$ & $160(91.40 \%)$ & & \\
\hline \multirow{2}{*}{\multicolumn{2}{|c|}{$\begin{array}{l}\text { The preferred style of } \\
\text { interface of students } \\
\text { of different types of } \\
\text { school }\end{array}$}} & $35(100 \%)$ & $65(92.90 \%)$ & $5(100 \%)$ & $165(94.30 \%)$ & \multirow[t]{2}{*}{2.79} & \multirow[t]{2}{*}{0.43} \\
\hline & & $0(0 \%)$ & $5(7.10 \%)$ & $0(0 \%)$ & $10(5.70 \%)$ & & \\
\hline
\end{tabular}

Table 9 shows that the score of portrait of network users of different genders is not statistically significant $(\mathrm{P}>0.05)$, and the score of portrait of network user of different ages is statistically significant $(\mathrm{P}<0.05)$. Students aged 18 and over score higher on issues related to current politics, religion and ethnicity than students under 18.

Table 9. T Test Analysis of the Score of Network User Portrait of Different Groups of Students

\begin{tabular}{|c|c|c|c|c|c|c|c|c|c|c|c|}
\hline & $\begin{array}{l}\text { Attention to } \\
\text { official } \\
\text { school media }\end{array}$ & $\begin{array}{l}\text { Attention to } \\
\text { Government } \\
\text { media }\end{array}$ & $\begin{array}{l}\text { Attention to } \\
\text { political } \\
\text { issues }\end{array}$ & $\begin{array}{l}\text { Attention to } \\
\text { religious } \\
\text { issues }\end{array}$ & $\begin{array}{l}\text { Attention to } \\
\text { nation issues }\end{array}$ & $\begin{array}{l}\text { Express } \\
\text { views and } \\
\text { comments on } \\
\text { current } \\
\text { events } \\
\text { through } \\
\text { WeChat, QQ } \\
\text { or Weibo }\end{array}$ & $\begin{array}{l}\text { Forward or } \\
\text { comment on } \\
\text { nation } \\
\text { information } \\
\text { through } \\
\text { WeChat, QQ } \\
\text { or Weibo }\end{array}$ & $\begin{array}{l}\text { Forward or } \\
\text { comment on } \\
\text { religious } \\
\text { information } \\
\text { through } \\
\text { WeChat, QQ } \\
\text { or Weibo }\end{array}$ & $\begin{array}{l}\text { Ever faced } \\
\text { with query } \\
\text { and negative } \\
\text { comments on } \\
\text { WeChat, QQ } \\
\text { or Weibo }\end{array}$ & & $\mathrm{p}$ \\
\hline Men & $3.63 \pm 0.70$ & $3.88 \pm 0.79$ & $4.00 \pm 0.72$ & $2.88 \pm 1.07$ & $3.38 \pm 0.70$ & $2.38 \pm 0.70$ & $2.63 \pm 0.70$ & $2.00 \pm 0.72$ & $2.13 \pm 0.79$ & 1.49 & 0.14 \\
\hline Women & $3.38 \pm 0.97$ & $3.57 \pm 0.86$ & $3.71 \pm 0.86$ & $3.18 \pm 0.87$ & $3.39 \pm 0.78$ & $2.18 \pm 0.72$ & $2.08 \pm 0.75$ & $1.90 \pm 0.82$ & $1.47 \pm 0.64$ & & \\
\hline Under 18 & $4.00 \pm 0.85$ & $3.67 \pm 0.98$ & $3.67 \pm 0.49$ & $3.00 \pm 0.00$ & $3.00 \pm 0.00$ & $2.33 \pm 0.49$ & $2.67 \pm 0.49$ & $2.00 \pm 0.00$ & $1.33 \pm 0.49$ & 2.48 & 0.01 \\
\hline 18 and over & $3.39 \pm 0.93$ & $3.61 \pm 0.85$ & $3.76 \pm 0.86$ & $3.15 \pm 0.93$ & $3.41 \pm 0.78$ & $2.20 \pm 0.73$ & $2.13 \pm 0.77$ & $1.91 \pm 0.82$ & $1.57 \pm 0.71$ & & \\
\hline
\end{tabular}

According to Table 10, there is no significant difference in the score of portrait of network user among students of different grades $(\mathrm{P}>0.05)$. And portraits of network user of students with different political identities and different types of schools are statistically significant. $(\mathrm{P}<0.05)$. 
Table 10. ANOVA of network user portrait scores for different groups of students

\begin{tabular}{|c|c|c|c|c|c|c|c|c|c|c|c|}
\hline & $\begin{array}{l}\text { Attention to } \\
\text { official school } \\
\text { media }\end{array}$ & $\begin{array}{l}\text { Attention to } \\
\text { Government } \\
\text { media }\end{array}$ & $\begin{array}{l}\text { Attention to } \\
\text { political } \\
\text { issues }\end{array}$ & $\begin{array}{l}\text { Attention to } \\
\text { religious } \\
\text { issues }\end{array}$ & $\begin{array}{l}\text { Attention to } \\
\text { nation issues }\end{array}$ & $\begin{array}{l}\text { Express views } \\
\text { and } \\
\text { comments on } \\
\text { current events } \\
\text { through } \\
\text { WeChat, QQ } \\
\text { or Weibo }\end{array}$ & $\begin{array}{l}\text { Forward or } \\
\text { comment on } \\
\text { nation } \\
\text { information } \\
\text { through } \\
\text { WeChat, QQ } \\
\text { or Weibo }\end{array}$ & $\begin{array}{l}\text { Forward or } \\
\text { comment on } \\
\text { religious } \\
\text { information } \\
\text { through } \\
\text { WeChat, QQ } \\
\text { or Weibo }\end{array}$ & $\begin{array}{l}\text { Ever faced } \\
\text { with query } \\
\text { and negative } \\
\text { comments on } \\
\text { WeChat, QQ } \\
\text { or Weibo }\end{array}$ & $\mathrm{t}$ & $\mathrm{p}$ \\
\hline Freshman & $3.35 \pm 0.77$ & $3.59 \pm 0.70$ & $3.76 \pm 0.73$ & $3.35 \pm 0.97$ & $3.59 \pm 0.60$ & $2.35 \pm 0.59$ & $2.18 \pm 0.71$ & $2.00 \pm 0.77$ & $1.59 \pm 0.70$ & 1.76 & 0.16 \\
\hline Sophomore & $3.22 \pm 0.42$ & $3.44 \pm 0.69$ & $3.78 \pm 0.79$ & $3.33 \pm 0.83$ & $3.56 \pm 0.84$ & $2.00 \pm 0.67$ & $2.22 \pm 0.64$ & $2.00 \pm 0.48$ & $1.33 \pm 0.48$ & & \\
\hline Junior & $3.60 \pm 1.03$ & $3.87 \pm 0.81$ & $4.00 \pm 0.74$ & $3.07 \pm 0.86$ & $3.47 \pm 0.62$ & $2.27 \pm 0.78$ & $2.40 \pm 0.81$ & $1.87 \pm 0.96$ & $1.80 \pm 0.75$ & & \\
\hline Senior & $3.44 \pm 1.18$ & $3.50 \pm 1.07$ & $3.50 \pm 1.01$ & $2.88 \pm 0.86$ & $3.00 \pm 0.87$ & $2.13 \pm 0.79$ & $1.88 \pm 0.79$ & $1.81 \pm 0.81$ & $1.44 \pm 0.71$ & & \\
\hline $\begin{array}{l}\text { Communist } \\
\text { Party members }\end{array}$ & $3.44 \pm 0.94$ & $3.69 \pm 0.77$ & $3.88 \pm 0.70$ & $3.13 \pm 0.93$ & $3.38 \pm 0.70$ & $1.94 \pm 0.66$ & $1.94 \pm 0.83$ & $1.69 \pm 0.85$ & $1.44 \pm 0.61$ & 3.37 & 0.02 \\
\hline $\begin{array}{l}\text { Communist } \\
\text { Party activists }\end{array}$ & $3.75 \pm 0.84$ & $3.88 \pm 0.33$ & $3.88 \pm 0.61$ & $3.00 \pm 0.51$ & $3.75 \pm 0.44$ & $2.63 \pm 0.70$ & $2.63 \pm 0.49$ & $2.25 \pm 0.84$ & $1.38 \pm 0.70$ & & \\
\hline $\begin{array}{l}\text { Communist } \\
\text { youth league } \\
\text { member }\end{array}$ & $3.25 \pm 0.83$ & $3.46 \pm 0.96$ & $3.63 \pm 0.95$ & $3.21 \pm 0.92$ & $3.25 \pm 0.88$ & $2.33 \pm 0.69$ & $2.17 \pm 0.75$ & $2.04 \pm 0.74$ & $1.58 \pm 0.64$ & & \\
\hline General public & $3.56 \pm 1.18$ & $3.67 \pm 0.95$ & $3.78 \pm 0.93$ & $3.11 \pm 1.11$ & $3.44 \pm 0.69$ & $2.00 \pm 0.67$ & $2.11 \pm 0.75$ & $1.67 \pm 0.67$ & $1.89 \pm 0.88$ & & \\
\hline $\begin{array}{l}985 \text { or } 211 \text { or } \\
\text { both }\end{array}$ & $3.14 \pm 1.26$ & $3.57 \pm 1.20$ & $3.86 \pm 0.65$ & $3.14 \pm 1.14$ & $3.43 \pm 0.74$ & $2.00 \pm 0.54$ & $2.14 \pm 0.85$ & $1.71 \pm 0.89$ & $1.57 \pm 0.50$ & 3.93 & 0.01 \\
\hline $\begin{array}{l}\text { Key } \\
\text { undergraduate }\end{array}$ & $3.71 \pm 0.80$ & $3.71 \pm 0.70$ & $3.79 \pm 0.68$ & $3.07 \pm 0.80$ & $3.50 \pm 0.50$ & $2.43 \pm 0.63$ & $2.43 \pm 0.73$ & $2.21 \pm 0.78$ & $1.57 \pm 0.83$ & & \\
\hline $\begin{array}{l}\text { General } \\
\text { undergraduate }\end{array}$ & $3.00 \pm 0.00$ & $3.00 \pm 0.00$ & $3.00 \pm 0.00$ & $3.00 \pm 0.00$ & $3.00 \pm 0.00$ & $1.00 \pm 0.00$ & $1.00 \pm 0.00$ & $1.00 \pm 0.00$ & $1.00 \pm 0.00$ & & \\
\hline $\begin{array}{l}\text { Higher } \\
\text { Vocational } \\
\text { Colleges }\end{array}$ & $3.37 \pm 0.90$ & $3.60 \pm 0.84$ & $3.74 \pm 0.94$ & $3.17 \pm 0.91$ & $3.34 \pm 0.86$ & $2.20 \pm 0.75$ & $2.09 \pm 0.73$ & $1.86 \pm 0.76$ & $1.57 \pm 0.69$ & & \\
\hline
\end{tabular}

\section{Discussion and Suggestion}

Under the realistic condition of space and distance, the ideological and political education in the network field is of vitally significance. The fast development of the Internet makes cyberspace called micro era gradually evolve into a new field of ideological struggle. On the one hand, it shows that the ideological struggle becoming more and more frequent and fierce. On the other hand, the perspective of network field for the education and management of foreign exchange students is feasible and forward-looking. What is more, the construction of network platform, the application of network means and technology is particularly important.

"The field of life is not the independent logical structure of the life process, life scenarios, life time and space of lifestyle (including thought, emotion, attitude, belief, action, etc), but organic whole which is based on the value of life that is related to the logic structure of multiple lifestyle in multiple life areas, and develop through multi-field integration in a certain mechanism." Therefore, in the education management of foreign exchange students, setting up a panoramic online ideological and political education platform helps to build the educational management field of foreign exchange of students.

\subsection{Construct a Network Discourse System that Meets the Requirements of Interaction}

In the education field, the target audience of the foreign exchange student are mainly 15-30 years old who have the following characteristics. First, they are against the traditional educational discourse system. Second, they have the strong sense of subject. And tendency of deauthorization. Third, they yearn for equal communication without center and the authority of releasing information transfer from traditional media to network individuals, which means equal dialogue between authority and the public, and dispell the status of official discourse. In today's new media environment, these situation lead to the traditional discourse system challenged and the from-Top-to-down One-way propagation mode excluded. The discourse system in the field of network education should be a field to propagate mainstream ideological values through contemporary exposition and answering questions of the core discourse instead of an ineffectual propagation. On the other hand, in the investment those who pay attention to the current political, state government new media, school official new media respectively 
gain the score of $3.75,3.61,3.42$ on average, which is the result of the first three positions of attention in the survey. In conclusion, exchange students pay more attention to current politics and national conditions, and do not fall into the mud of entertainment generalization. "In order to build broad-based communication discourse system, communication expressions access should be adjusted. The important points of discourse system is the critical transformation of discourse expression, which call for adapting to the network ecology which have the following characteristics, practice integration of network ecology, dissemination of immediacy, expression of fragmentation, interactivity, etc." In response to the above changes in new media communication, in the process of constructing the field of foreign exchange generation network, we should find out the network discourse system and communication mode on the basis of the core connotation of Marxist advanced thought that are widely accepted by the general public. Promote the transformation of one-way educational discourse system to lively interactive discourse system, which is helpful to achieve transform from lofty to approachable and improve the appeal and acceptance of discourse system. Last but not least, not only to ensure the integrity of content of expression, but also to enhance the regulatory power of the way of discourse by adjusting time and frequency of information release and the rule of discourse of expression.

\subsection{Build a High-Quality Field of Network Education}

$94.7 \%$ of the respondents expressed a high demand for the network interface, hoping to obtain a concise and intuitive perspective. In order to adapt to interactivity of usage, it is necessary to make full use of image and media interaction, achieving visualization. The construction of network education service platform is not only need to consider the hardware facilities such as appearance design and module construction, but need to consider cultural feelings, space construction and other software design. The perfect campus service network platform can solve the students' specific affairs before going abroad conveniently, such as project application, credit mutual recognition, receiving notifications, alumni exchange, which can reduce emotional loss during the applying process and enhance students' sense of identity and belonging. At the same time, ideological and political education in the service is more efficient than direct ideological and political education. In order to educate and manage foreign exchange students, network space section of education and management to foreign exchange students should be set up which is only service for them. The function of this platform including releasing information and communication interactively. The construction of network space not only provides a platform for college students to communicate and supervise, but provides opportunities for exchange students to communicate with their home college teachers, strengthening emotional construction and cultural identity.

\subsection{Construct the Education Model Considering Time, Space and Subject}

It is very important to grasp the timing of the construction of field of network education. The new media era is characterized by fragmentation and immediacy, so in order to catch the great timeliness of the news, the heat of the topic, the fragmented background and so on should be considered when construct the field of network education, avoiding educational positions challenged Encourage the organizers of network education activities to grasp the mainstream ideological, seize the opportunity and way in time when major events happened, and make a strong reflection at the first time. At the same time, living in foreign space, the desire for emotional attention is beyond doubt. According to the survey, $87.1 \%$ of all respondents said there was a great need for collective and other concerns during the exchange process. So in the process of building the field of network education, we should devote great attention to emotion, such as holiday greetings, regular greetings, thoughtful service. It deserves to highlight that emotional concerns should be the genuine caring instead of the formalism, so that the foundation of communication for educational management can be established.

WeChat Public Platform, micro-blog, Bilibili station, tiktok and other new media value propagation platform should become a platform for foreign exchange students' online education field. Through the orderly organization and processing of these platforms, the education content is orderly enbedded in the mind of foreign exchange students, and its effect can stand the verification. The common network platform such as WeChat official is an ideal network education platform because of its "one to many" mode of communication, the expression ways with current audience acceptance, more expressive, and the huge number of users. At the same time, the WeChat Public Platform can send articles with ideology to the users, spreading widely through users' comments, forwarding which enhances further impact and achieve orderly internal interaction.

In addition to the managers of in the field of network education, people such as "public professionals on the Internet" and "opinion leader" should become the core force of education. No matter what way or platform are chosen, the direction of serving for socialist education must not be changed. If the field of network education does not have the right to speak and let the thought spread at will, it will lose the space and efficiency of communication and the position of network ideological and political education. In order to grasp the initiative of network ideological and political education, it is necessary to cultivate spokesmen to obtain value orientation who get the key seat to release information. These spokesmen not only check the network information, but also guide the value, who are the invisible managers and supervisors in the field of online education. These 
spokesmen not only check the network information, but also guide the value, who are the invisible managers and supervisors in the field of online education

\subsection{Building the Institutionalized Management of Exchange Students' Network Education Field}

Relying on the online new media way to carry on the decentralized management to the foreign exchange student, the management system must be formulated under the new media network environment. For example, to build a field of education in a new media platform, it is necessary to clarify the frequency of contact, norms of words, deeds and learning norms and other related institutional standards. With the real identity, network new media is not an extrajudicial place. Due to the fact that the ideological and political educators in colleges or universities can not check the users' identity and the virtual nature of network, the virtual nature of network communication makes some users lose the constraints of these behavior and speech hiding behind the network,. Carrying out the real name system of users is to let the users who log on to the campus network platform use the prescribed and unique ID login, such as the student ID or worker ID. On the one hand, it is convenient for foreign exchange students to enjoy the services provided by campus network service platform with their own student identity. On the other hand, it can remind exchange students of their identity. The real name of the users in the network education field is convenient to observe the user's dynamics in time, to find the behavior changes caused by the body, thought and other reasons in time. In the big data mode, and to track the users with inappropriate words and deeds, and to deal with and guide them in time. In big data mode, behavioral changes, caused by physical and psychological factors, can be discovered in time, so that users with inappropriate words and deeds can be tracked and lead to the right way timely.

\section{References}

Ao Yongchun, \& Zhang Zhenqing. (2020). Construction of Cultural Field of Ideological and Political Education for College Students. School Party Building and Ideological Education, 2020(05), 85-87.

Bourdieu, Hua Kant, Li Meng et al. (1998). Practice and Reflection - A Guide to Social Science. Reflection Beijing: Central Compiler Press.

Cai Chunhua. (2019). Thinking and Research on College Counselors' Work in the New Media Age. News Research Guide, 10(22), 237-238.

Deng Peng, \& Chen Shuwen. (2019). Analysis on the Right of Speech in Ideological and Political Education in Colleges and Universities. Guide to Ideological and Theoretical Education, (09), 103-107.

Ding Yuan. (2019). Analysis on the Management Mechanism of College Student Party Members in New Media. Communications research, 3(32), 237-239.

Du Shiju, \& Liu Lin. (2018). The "micro-era" dominates the ideological field orientation and discourse transformation. Ideological and theoretical education, (10), 79-84.

Liu Qiucheng, Liu Daoping, Lu Xiao, \& Chen Jinxiu. (2020). The leading path of ideological work in colleges and universities in network ecological field. Journal of Shanghai University of Technology (Social Sciences Edition), (02), 155-160.

Lu Jinxin. (2019). Study on the Management of Ideological and Political Education from the Perspective of Public Opinion in Colleges and Universities. Modern communication, 2019(21), 163-167.

Ma Lan, \& Niu Lujing. (2020). The interactive design strategy of network education virtual learning community based on field theory. Art and Design (Theory), (06), 87-89.

Peng Juan. (2019). The Innovation of College Students' Ideological and Political Education in the New Media (Doctoral thesis, University Of Shanxi). Retrieved http://fffg208e51c2dd88406685526280e50de659swcxxf0vpx0qk6cnp.fxyh.librra.gdufs.edu.cn/KCMS/detai 1/detail.aspx dbname $=$ CDFDLAST2020\&filename $=1019177276 . \mathrm{nh}$

Wang Yuefen, \& qu Changhai. (2018). A Study on the Life of Socialist Core Values from the Perspective of Field Area. Scientific socialism, 2018(4), 51.

Zhao Yanwu, Li Xin, Zhang Wei, \& Ramir S. Austria. (2019). Analysis on the Dilemma and Solutions of Educational Managers Under the New Media. Communications research, 3(33), 232-234.

\section{Copyrights}

Copyright for this article is retained by the author(s), with first publication rights granted to the journal.

This is an open-access article distributed under the terms and conditions of the Creative Commons Attribution license (http://creativecommons.org/licenses/by/4.0/). 